Beaumont Compressed Air Engine Company at Stratford with a separate engine, hauling an ordinary passenger car behind it are likely to bring the question prominently before the notice of tramway companies, and the hopeful remarks made before the last meeting of the British Association by Sir Frederick Bramwell, with regard to the use of compressed air, must have contributed towards the same result. The experience of the writer, who has been longer at work on the subject than either of the representatives of the systems referred to is, however, so much opposed to their proposals, that he does not feel himself to be an altogether unbiased critic of their proceedings. It is sincerely to be hoped, for the sake of suffering horseflesh, and in order to promote the expansion of intramural locomotion throughout the country, that a fair trial may soon be given to the rival systems, including electricity. This, however, is but a remote contingency if tramway companies continue to adhere to the principle, or rather no principle, that they have to get everything, and the men who add to their dividends nothing, for their pains. The writer's car, which can be seen at work by any one interested, is entirely self-contained, and offers absolutely no obstructions to the convenience of passengers, and it carries forty of them a distance of more then seven miles with a low and safe pressure of air in the receivers, and without replenishing the supply. The distance it would travel with the pressure used in Col. Beaumont's engine is over twenty miles with one charge of air. The weight complete, including the fittings for passengers, is less than that of any compressed air tramway engine which the writer knows of, hauling a tramway car behind it.

W. D. SCOTT MONCRIEFF

\section{SEA FROTH}

I HAVE just read with interest Dr. Gladstone's article in NATURE (vol. xxv. p. 33) on "Sea Froth." I venture to inclose, as an illustration of his nephew's observations, portion of a description of such froth as witnessed by myself during a Mauritius hurricane, extracted from a book I am now publishing. It will be noticed how that close observer of nature, Bernardin de St. Pierre, depicted the same a century since in the same locality.

"This remnant of wreck had been washed bodily out of the deep water to within the outer barrier of reef on to a ledge, and was wholly out of the water, which position thus saved it from entire destruction, as only a portion of the enormous waves, which broke along the entire reef for miles, actually struck the remaining moiety, for the vessel had broken in two, and the stern-half had entirely been destroyed by the prodigious force of the breakers, the sound of which oceanic passion rose high above the din of the nearer dashing waves. Without the reef, sea and sky, ocean and air, were commingled, indistinguishable, 'a complete annihilation of the limit between sea and air.' Within the reef, the shallower sea presented a most wonderful sight, such as few can describe; it was what Bernardin de St. Pierre, nearly a century since, termed ${ }^{1}$ ' Une vaste nappe d'écumes blanches creusés de vagues noires et profondes'; and what Victor Hugo, in his 'Travailleurs de la Mer,' has aptly described in European waters as 'd'eau de savon,' " a sea of soapsuds and lather, the lather flying in snowy flakes like thistle-down.

The description given by Bernardin de St. Pierre of the view from the seashore on the north-east side of Mauritius is so true, and so evidently sketched from nature, that it, will ever bear repetition. "Chaque lame qui venait se briser sur la côte s'avançait en mugissant jusqu'au fond des anses, et y jetait des galets à plus de cinquante pieds dans les terres; puis venant à se retirer, elle découvrait une grande partie du lit du rivage, dont elle roulait des cailloux avec un bruit rauque et affreux. La mer, soulevée par le vent grossissait à chaque instant, et tout le canal compris entre cette ile et l'ile Ambre n'était qu'une vaste nappe d'écumes blanches creusées de vagues noires et profondes. Ces écumes s'amassaient dans le fond des anses, à plus de six pieds de hauteur, et le vent qui en balayait la surface les portait pardessus l'escarpement du rivage à plus d'une demi-lieue dans les terres, A leurs flocons blancs et innombrables qui étaient chassés horizontalement jusqu 'au pied des montagnes, on eût dit d'une neige qui sortait de la mer." "Paul et Virginie" (Ed. 1879 , Hachette).

" La mer à perte de vue était blanche; dix lieues d'eau de savon em. plissaient l'horizon."
"[Both the above authors, incomparable in their respective lines, have, it will be observed, used somewhat similar imagery, which is sufficient proof of its fidelity to realistic facts. I have only seen one painter's drawing which has at all even faintly attempted to copy these soapsuds of the sea, 'L'énorme écume échevelait toutes les roches,' and that only on a small scale, viz. Mr. Frank Miles' study of a curling wave before it breaks on 'An Ocean Coast : Llangravieg, Cardiganshire' (No. 342), in Gallery No. IV. of last year's Academy. ${ }^{1}$ The rendering of the blotches of foam, ${ }^{2}$ which curdle on the hollow curved side and translucent crest of the breaking wave, are praiseworthy in their transcription, although their perspective has been blamed by some critics. 'L'écume ressemblait à la salive d'un léviathan.' Mr. Miles ought to have given to his drawing the lines from Keats, quoted by Ruskin as the perfect expression of the peculiar action with which foam rolls down a long wave:

" ' Down whose green back the short-lived foam, all hoar,

Bursts gradual with a wayward indolence.'

I cannot forbear giving Ruskin's imagery, as bearing out the above similes:- "The water from its prolonged agitation is beaten not into mere creaming foam, but into masses of accumulated yeast, which hang in ropes and wreaths from wave to wave, and where one curls over to break, form a festoon like a drapery from its edge; these are taken up by the wind, not in dissipating dust, but boldly in writhing, hanging, coiling unasses, which make the air white and thick as with snow, only the flakes are a foot or two long each : the surges themselves are full of foam in their very bodies, underneath, making them white all through, as the water is under a great cataract and their masses, being thus half water and half air, are torn to pieces by the wind whenever they rise, and carried away in roaring smoke, which chokes and strangles like actual water.' See 'Of Truth of Water' ('Modern Painters,' vol. i. part 2, sec. v. Chap. III. p. 375.'

\section{S. P. OLIVER}

\section{ON THE HEIGHTS OF THE RIVERS NILE AND THAMES}

COLONEL DONNELLY has put into my hands information from which the following results have been obtained :-

The information regarding the Nile has been derived from General Stone (Pacha), who has forwarded to the Science and Art Department a graphical representation exhibiting the height of the River Nile above the zero of the Cairo Nilometer for every five days, or six for each month from the beginning of 1849 to the end of 1878 .

The information regarding the Thames has been derived from Sir F. W. E. Nicolson, who has forwarded a daily record of the levels on the lower sill of Teddington Lock when the tidal water has all drained off. This record extends from the beginning of 1860 to the end of 1880 .

At present it is impossible to deduce from these records the volume of water which passes in unit of time across a section of these rivers : nevertheless the results give us a good deal of information, for we may be sure that an increase in depth denotes an increase in the volume of the water carried by the river and a decrease in depth a diminution of the same.

The results deduced I have embodied in a series of tables. In Table I. the yearly sum represents the whole area above the zero of the Cairo Nilometer of the graphical curve for the year in small squares whose base represents five days, and height one decimetre.

I An extribition of paintings and drawings of "The Sea" is announced this winter, as to be held in the Gallery of the Fine Art Society, 148, New Bond Street. laine." 
In Table II. we have the dates of maximum height of the Nile, reckoned from the beginning of September as a zero date and the sums of the numbers for two years taken.

In Table III. the numbers record sums for two years of monthly means of the water level at Teddington. reckoned in feet and decimals of a foot ; that is to say each number must be divided by 24 in order to get the mean of the two years.

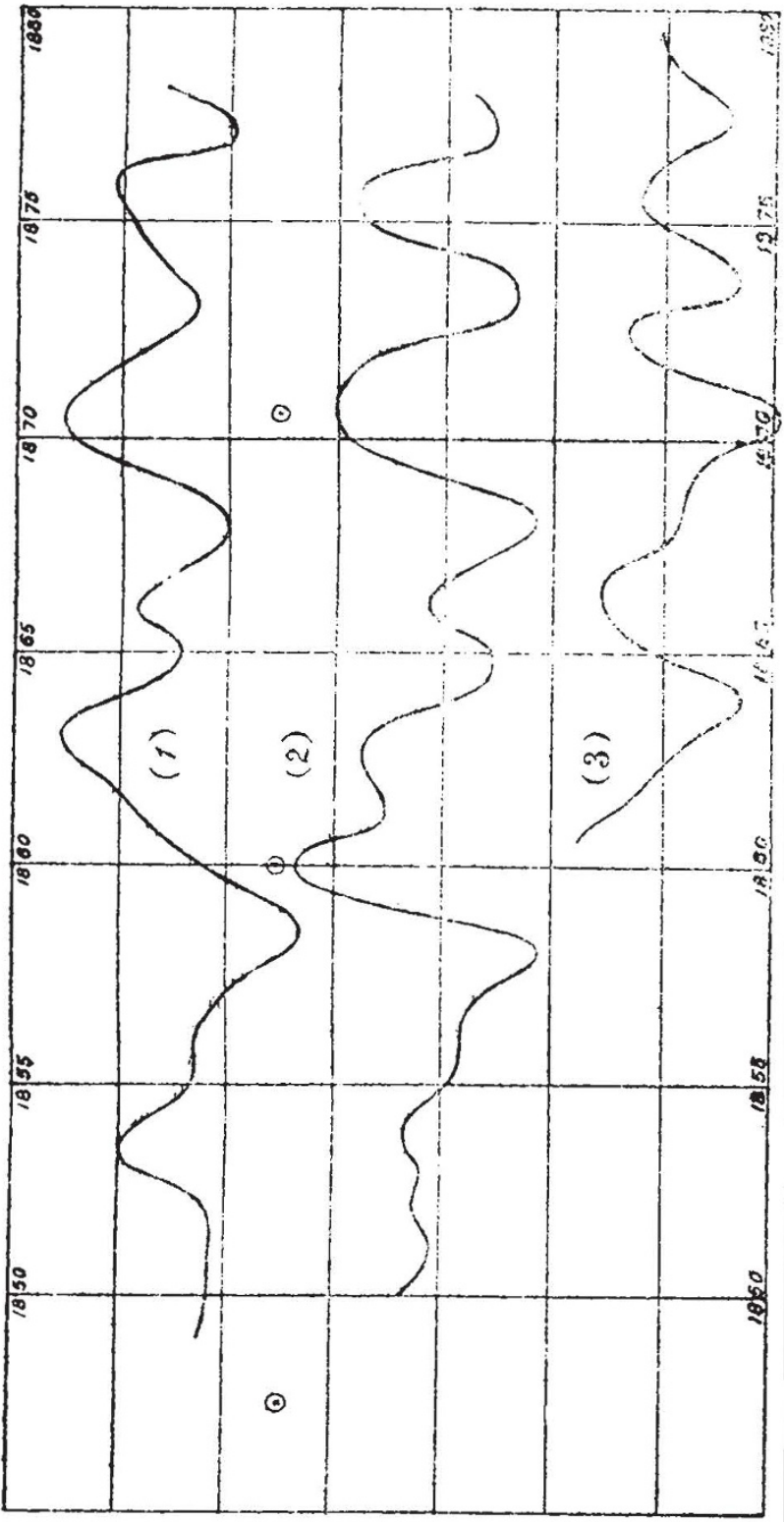

TABLE I. - Recording the Yearly Heights of the River Nike in the

\begin{tabular}{|c|c|c|c|c|c|c|c|}
\hline \multicolumn{8}{|c|}{ manner already described } \\
\hline $\begin{array}{l}\text { Year. } \\
\text { I } 849\end{array}$ & $\begin{array}{l}\text { Heigh:. } \\
2130\end{array}$ & & $\begin{array}{l}\text { Year. } \\
1859\end{array}$ & $\begin{array}{l}\text { Ireight. } \\
\text { 1766 }\end{array}$ & & $\begin{array}{l}\text { Year. } \\
\mathbf{1} 869\end{array}$ & $\begin{array}{l}\text { Height. } \\
2284\end{array}$ \\
\hline 850 & 2080 & $\begin{array}{l}\cdots \\
\ldots\end{array}$ & 1860 & 2098 & $\ldots$ & I 870 & 2701 \\
\hline 85 & 2077 & $\ldots$ & IS6I & 2368 & $\ldots$ & IS $S_{71}$ & 2718 \\
\hline 35 & 2078 & $\ldots$ & IS62 & 2574 & $\ldots$ & $1 \$ 72$ & 2.404 \\
\hline & 2434 & $\ldots$ & IS & 2765 & $\ldots$ & $1 \$ 73$ & 2142 \\
\hline & 2425 & $\ldots$ & 18 & 24 & $\ldots$ & 1874 & $23 \mathrm{r} 7$ \\
\hline & 2173 & $\ldots$ & 1865 & 2229 & $\ldots$ & 1875 & 2463 \\
\hline & $21_{4} I$ & $\ldots$ & & 2432 & .. & 1876 & 2541 \\
\hline & 2016 & $\ldots$ & 1867 & 2208 & $\ldots$ & 1877 & I98t \\
\hline & 1736 & $\ldots$ & 1868 & 2003 & $\ldots$ & I 878 & 2290 \\
\hline
\end{tabular}

TABLE II.-Ricording the Dates of Maximum Height of the Raver Nile in the manner already described

Vear. Date of Year. Date of Year. Date of

1849-50 max. 64 max.

$\begin{array}{llllllll}1849-50 & 64 & \ldots & 1859.60 & 116 & \ldots & 1869.70 & 96\end{array}$

$\begin{array}{llllllll}1850.5 \mathrm{I} & 54 & \ldots & 1850.61 & 80 & \ldots & 1870-71 & 100\end{array}$

$\begin{array}{llllllll}1851 \cdot 52 & 63 & \ldots & 1861.62 & 84 & \ldots & 1871.72 & 79\end{array}$

$\begin{array}{llllllll}1852-53 & 60 & \ldots & 1862-63 & 89 & \ldots & 1872-73 & 22\end{array}$

$\begin{array}{llllllll}1853-54 & 68 & \cdots & 1863-64 & 4 \mathrm{r} & \ldots & 1873-74 & 33\end{array}$

$\begin{array}{llllllll}1854-55 & 48 & \ldots & 1864-65 & 33 & \ldots & 1874-75 & 88\end{array}$

$\begin{array}{llllllll}1855.56 & 43 & \ldots & 1865.66 & 57 & \ldots & 1875.76 & 82\end{array}$

$\begin{array}{llllllll}1556-57 & 37 & \ldots & 1866-67 & 3 S & \ldots & 1876-77 & 31\end{array}$

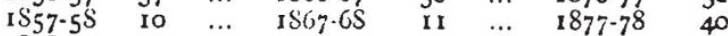

$\begin{array}{llllll}1858-59 & 71 & \ldots & 1868-69 & 52\end{array}$

TABLE III.-Recording the Watir Level at Tiddington in the Ycar. Ireights. mannitr alreaily describid

Ycar. Ileights. Ycar. Heights. Year. Heights.
$1860-61$

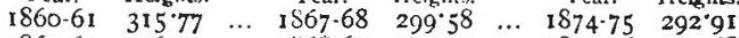

$\begin{array}{llllllll}1 \$ 61-62 & 306.52 & \ldots & 1 \$ 68.60 & 297 \cdot 21 & \ldots & 1875.76 & 304.68\end{array}$

$\begin{array}{lllllllll}1862.63 & 299.83 & \ldots & 1869.70 & 292.29 & \ldots & 1876-77 & 299.41\end{array}$

$\begin{array}{lllllllll}1863.64 & 288 \cdot 27 & \ldots & \text { IS70 7I } & 278.77 & \ldots & 1877-78 & 288.81\end{array}$

$\begin{array}{lllllllll}1864^{-65} & 294^{\circ} 63 & \ldots & 1871 \cdot 72 & 294^{\circ} 90 & \ldots & 1878.79 & 296.32\end{array}$

$\begin{array}{lllllllll}1865.66 & 308.67 & \ldots & 1872.73 & 306.10 & \ldots & 1879-80 & 300.62\end{array}$

$\begin{array}{llllll}1866-67 & 312 \cdot 11 & \ldots & 1873 \cdot 74 & 286.82\end{array}$

A diagram likewise accompanies this, in which the results are graphically represented, curve (I) denoting the results of Table I., curve (2) those of Table II., and curve (3) those of Table III. In this diagram the dates of sunspot maxima are likewise indicated. From an inspection of this diagram we may perhaps deduce the following conclusions :-

I. The curve representing the heights of the River Nile and that representing the dates of maximum height are very like each other, a maximum height corresponding generally to a late date of maximum rise.

2. There is also a considerable likeness between the Nile curve and that for the River Thames.

3. There appears to be a maximum in these curves at or somcwhat after the date of maximum sun-spots, but they have more than one maximum for one sun-spot cycle.

It would be extremely interesting if this comparison could be still further extencied. BALFOLR STEWART

\section{OLEO-MARGARINE}

I $T$ is now dourbtless known to most people that much of what by courtesy goes by the name of butter is only verydistantly related to the dairy produce which has hitherto enjoyed a prescriptive right to that appellation. If any of our readers were ignorant of this fact, the interesting and instructive statement which the Chairman of Committee, in his capacity as a private nember, laid before the House during the last Session will have fully enlightened them on that point, as indeed it enlightened, and seemingly astonished, Honourable Members. During the past ten years a new industry has been created. It came into existence very quietly, and under the taint of illegitimacy, and consequently the world in general knew very little about it. Thanks, however, to the operations of Sanitary Boards, Officers of Health, and Food Analysts, it was eventually dragged out into the light of day; when, despite the circumstance that the greater part of its existence had been spent in out-of-the-way places and without the fostering recognition of authority, it stood revealed as an astonishingly well-grown and highly prosperous business. The industry in the outset was set going to manufacture a product from beef-suet to be used in the adulteration of butter, and enormous quantities of this product were made in this country and in America for this purpose. The fraud was, however, so repeatedly exposed, and convictions against grocers and others selling this adulterated butter were so frequently obtained, that the vendors were driven to so far take the public into their confidence as to declare that the product was "a butter-substitute," and hence arose the euphemism of "butterine," by which it be- 